\title{
La resistencia a los sulfatos de los cementos portland y su grado de finura de molido: análisis de su relación
}

\section{The sulphate resistance of the portland cements and their grinding fineness degree: analysis of their relation}

R. TALERO, J. PALACIOS Y J. E. MORALES ICCET/CSIC

RESUMEN

Este trabajo ha demostrado la gran influencia que tiene la superficie especifica de un cemento portland en su calificación como de alta o baja resistencia al ataque del ion sulfato mediante el método acelerado de ensayo AST'M C 452 .

Para este objetivo se han ensayado dos cementos portland mediante dicho método de ensayo. Un cemento portland PY $(3,83 \% C$ A),Tipo $V(2)$ con 3 diferentes superficies especificas.

Los resultados experimentales obtenidos han demostrado que, de acuerdo con el método ASTM C 452, un cemento portland tipo $P$ III (2) puede ser calificado como de Tipo PY Tipo $V(2)$.
ABSTRACT

This work has demonstrated the great influence that the specific surface of a Portland cement has on its qualification as a high or low resistance to sulfate ion attack $-S I A$, by means of the accelerated method ASTM C 452

For that purpose two Portland cements have been tested by means of the that method. A Portland cement PY $\left(3,83 \%\left(\begin{array}{c}1 \\ 1\end{array}\right)(\right.$ lype $V(2))$ with 3 different specific surfaces.

The experimental results obtained have demonstrated that, according to the ASTM C452-68 method, a Portland Cement Type III(2) can be qualified as from Type V(2), and vice verse, according to its specific surface being adequated, or not, for each objective.

\section{INTRODUCCIÓN}

Desde el primer intento que se realizó para poner a punto el método de ensayo ASTM C 452 (1), alrededor de 1956 hasta nuestros días, los estudios llevados a cabo con relación al mismo han confirmado claramente que la proporcionalidad que debe de existir entre el contenido de $\mathrm{C}_{3} \mathrm{~A}$ de un cemento portland y sus respectivos valores de $\overline{\Delta \mathrm{L}}{ }^{*}{ }_{28 \mathrm{~d}}(\%)$ (antes) e $\overline{\Delta \mathrm{L}}{ }^{*}{ }_{14 \mathrm{~d}}(\%)$ (en la actualidad) no es exacta, sino más bien una mayor o menor, aproximación dependiendo del caso estudiado.

Los motivos de esta exacta proporcionalidad no se han determinado todavía, pero se considera que en general y entre ellos se pueden mencionar los siguientes:

(*) incremento de longitud a 28 y 14 días, respectivamente.

\section{INTRODUCTION}

Since the first attempt in designing an accelerated method of test ASTM ( 452(1) around 1956 to our days, the studies carried out concernign this topic have fairly confirmed that the proportionality between the ('A content of a Portland cement and its respective $\overrightarrow{\Delta L}_{28 d}(\%)^{*}$ value(the old value considered in the method), $\Delta \bar{L}_{14 d}(\%)^{*}$ value(the one considered nowadays) is not exact but a mere approximation or quite an approximation depending on the case studied.

The causes of this fact have not been determined but it is generally considered that among them it can be mentioned the folowing:

(*) length increment at 28 and 14 days, respectively. 
a) El grado de cristalinidad del $\mathrm{C}_{3} \mathrm{~A}$ del cemento portland ensayado, el cual a su vez es función de la velocidad de enfriamiento del clínker correspondiente.

b) Los diferentes tipos cristalinos de $\mathrm{C}_{3} \mathrm{~A}$, cúbico, ortorrómbico, tetragonal y monoclínico, resultantes de la sustitución parcial de $\mathrm{Ca}^{2+}$ por $2 \mathrm{Na}^{+}$, los cuales asimismo tendrían más o menos reactividad.

c) El tamaño de grano resultante del grado de finura de molido de su respectivo clínker.

d) Etc., etc.

De todos, el motivo c) ha sido el que nos ha movido a llevar a cabo este trabajo de investigación, con el fin de encontrar cómo afecta este parámetro al comportamiento de dos cementos portland: uno de moderada resistencia al ataque del yeso $(\mathrm{P})$, otro de elevada resistencia a dicho ataque agresivo (PY) y de acuerdo con lo que define al respecto la norma ASTM C150-85 (2) incluida en la ASTM C452.

Por otra parte también se intentó confirmar cómo este parámetro afectó a la relación $\mathrm{a} / \mathrm{c}=\mathrm{w} / \mathrm{c}$ obtenida mediante el método "mesa de sacudidas" o norma ASTM C 452-68 (3) y su influencia en los valores de $\overline{\Delta \mathrm{L}}$ determinados.

\section{OBJETIVOS}

El principal objetivo de este trabajo es determinar cómo el grado de finura de molido, GFM, de cementos portland, de moderada y elevada resistencia al ataque de los iones sulfato, afecta a su respectiva calificación después de ser ensayados mediante las dos versiones del método acelerado de ensayo ASTM C 452 .

\section{PARTE EXPERIMENTAL}

Tal y como se expuso anteriormente, dos cementos portland, PY y $\mathrm{P}$, -cuyo análisis químico se encuentra en la Tabla 1-:

$1^{\circ}$ Fueron molidos con diferentes grados de finura de molido, GFM, o Superficie Específica (Blaine), es decir,

-PY, con 3 diferentes GFM: 3811,4617 y $6200 \mathrm{~cm}^{2} / \mathrm{g}$,

-P, con 4 diferentes GFM: $3100,3969,4727$ y 5500 $\mathrm{cm}^{2} / \mathrm{g}$. a) The crystalinity degree of $C_{3} A$ of the Portland cement tested resulted from the cooling speed in their respective clinker.

b) The cubic, orthorhombic, tetragonal and monoclinic $C_{f} A$ type resulted from the sustitution degree of $2 \mathrm{Na}^{+}$ to $\mathrm{Ca}^{2+}$ in obtaining their respective crystaline net, which, in addition, would have more or less reactivity.

c) The grain size resulting from the grinding fineness degree or their respective clinker.

d) etc.

Cause c) was the one which push us to carry out this research work in order to find out how this parameter affected the behaviour of both Portland cements, one of them qualified as high resistant to sulfate ion attack(PY) and the other as moderate resistant to such attack(P), according to the ASTMC 150-85(2) standard included in the ASTM C 452 test.

On the other hand, it wass intended to confirm how this parameter affected the ratio $(a / c) \cdot(w / c)$ obtained by means of the "flow table" method or the ASTM C $452-68(3)$ method and its influence on the $\overline{\Delta L}$ reached.

\section{OBJETIVES}

The major aims of this work is to determine how the grinding fineness degree if a moderate and high resistant to sulfate ion attack, SIO, Portland cements, respectively, affects their respective qualification after being tested by means of the couple of versions of the AST'M (' 452 accelerated method.

\section{EXPERIMENTAL PROCEDURE}

As it was mentioned above, two Portland cements, a $P Y$ and $a P$, (whose chemical analysis are given in Table 1).

1st. Were ground according to different grinding fineness degre (GFM) or Specific Surface (Blaine). that is to say,

- PY with 3 different GHM: 3811,4617 and $6200 \mathrm{~cm}^{2} \mathrm{~g}$,

- $P$ with 4 different GFM: 3100,3969,4727 and $5500 \mathrm{~cm}^{2} / \mathrm{g}$. 
$2^{\circ}$ Se les aplicó el método acelerado de ensayo ASTM C 452

.en su versión ASTM C 452-68 (3) ( $\mathrm{a} / \mathrm{c}=$ variable y determinada mediante la "mesa de sacudidas"), y

.en su versión ASTM C 452-75 (4) o relación a/c = 0,485

\section{RESULTADOS EXPERIMENTALES}

Los resultados obtenidos experimentalmente se muestran en las Figs. 1 y 2 . Su discusión es como sigue:

A) La Fig. 1 muestra los valores obtenidos del $\overrightarrow{\Delta L}_{14 d}$ en función de la superficie específica del respectivo cemento portland ensayado, por cada familia de probetas preparada.

Dado el interés e importancia tecnológica de tales valores, se deberán destacar los siguientes puntos:

$1^{\circ}$ Para cada versión empleada del método ASTM C 452, existe un adecuado valor de la superficie específica de ambos

cementos portland que proporciona un mínimo valor de $\overline{\Delta L}_{14 d}$ en sus probetas y viceversa. Este adecuado valor debería denominarse "Óptimo de Finura de Molido" (OFM) de un cemento portland y es aquél mediante el cual proporcionará un mínimo valor de $\overline{\Delta L}_{14 d}$ al ser ensayado mediante el método de ensayo ASTM C 452-75.

Para los cementos portland aquí ensayados se ha encontrado un OFM de $4617 \mathrm{~cm}^{2} / \mathrm{g}$ para el PY y de $3969 \mathrm{~cm}^{2} / \mathrm{g}$ para el $\mathrm{P}$

$2^{\circ}$ El OFM obtenido para el cemento portland $\mathrm{P}$ $\left(3.969 \mathrm{~cm}^{2} / \mathrm{g}\right.$ ) permite calificar este cemento como de elevada resistencia al ataque de los iones sulfato, RS, mediante ambas versiones empleadas del método de ensayo ASTM C 452, con objeto de ensayarlo y de acuerdo con la Tabla $2 \mathrm{a}$ "Requerimientos Físicos Opcionales" de la norma ASTM C 150-85 (2), ya que el valor correspondiente del $\overline{\Delta \mathrm{L}}_{14 \mathrm{~d}}$ obtenido ha sido siempre $<0,040 \%$.

No obstante, y de acuerdo con los "Requerimientos Químicos Opcionales" de la Tabla 1 de dicha norma (2), este cemento portland tendría que ser calificado como de "moderada RS" debido a su contenido de $\mathrm{C}_{3} \mathrm{~A}=6,83 \%<8 \%(2)$.

$3^{\circ}$ Los valores de superficie específica incluidos, y viceversa, mencionados son: 2nd. It was applied the accelerated method of test, version ASTM C 452-68(3)(ratio $w / c$ variable and determined by means of the "flow table" method of flow=constant) and version ASTM C 452-75(4) or ratio $w / c \quad 0,485$.

\section{EXPERIMENTAL RESULTS}

The results experimentally obtained are shown in the Figures 1 and 2. Their discussion is given as follow:

1.- Fig. I shows the $\overline{\Delta L}_{14 d}$ values obtained, as function of the specific surface of the respective Portland cement tested, for each family of specimens prepared.

For its interest and its possible technological importance, it should remarked the following points:

\subsection{For each version of the ASTM (' 452 method} employed, there is an adequate velue of the specific surface of the Portland cements PY and P tested end thus, both cements have a respective value of $\Delta \bar{L}_{14 \mathrm{~d}}$ and the other way round, that is to say, when both Portland cements have had lower and higher values of the specific surface than their respective minimum. This adequate value should be named as "Grinding fineness optimum "(OFM) of a Portland cement by means of which, it will be show the $\overline{\Delta L}$ minimum value after applyiing the ASTM C 452-75 test. For the Portland cements tested, it has been found a OHM value of $4617 \mathrm{~cm}^{2} / \mathrm{g}$ for $P Y$ and $3969 \mathrm{~cm}^{2} / \mathrm{g}$ for $P$.

\subsection{The OFM obtained for the Portland cement P} $\left(3969 \mathrm{~cm}^{2} / \mathrm{g}\right)$ allows to qualify this cement as high resistant to sulfate ion attack(SIA) for both versions of the ASTM C 452 employed for its tests and according to the Table $2 a$ "Optional Physical Requirements" of the ASTM standard, since any value of $\overline{\Delta L}_{14 d}$ obtained has always been $0.040 \%$.

Nevertheless and according to the "Optional Chemical Requirements" of Table I of the standard mentioned above, this Portland cement should be qualified as moderated sulfate resistance since its content of $C_{3} A \quad 6.83 \% \quad 8.0 \%(2)$.

1.3. The causes included between "... and the other way round" mentioned above, are: 


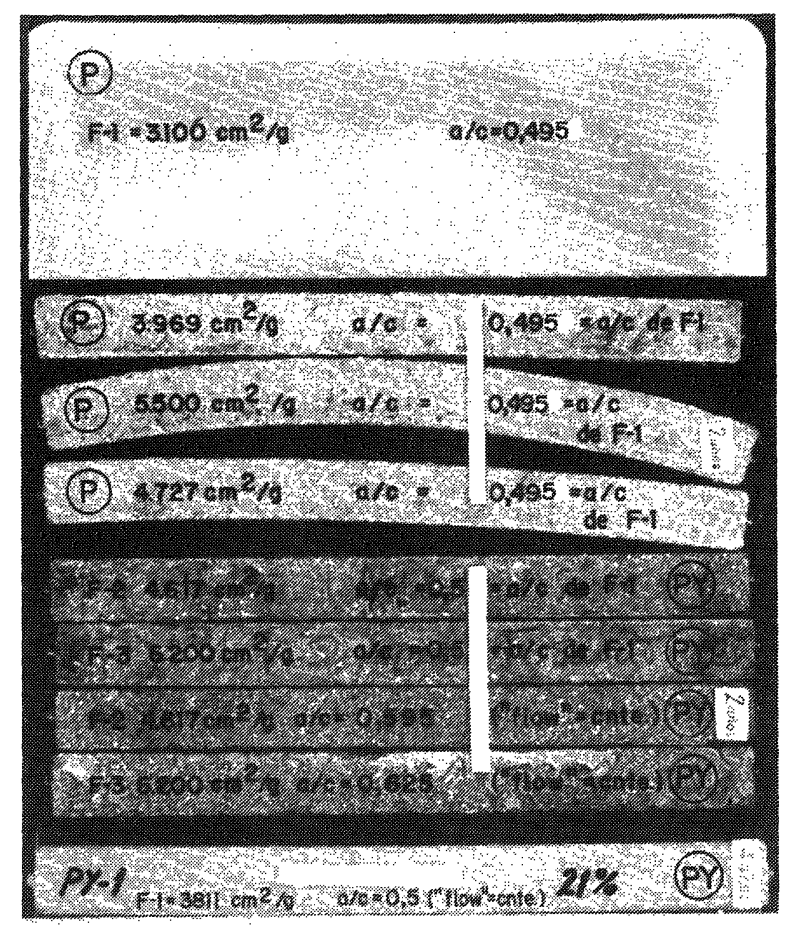

Foto 1.- Probetas de los cementos portland P y PY ensayados según el método IET/RT 86: $\overline{\Delta L}$. Edad 2 y 4 años.

Photo 1.- Specimens of the portland cements $P$ and $P Y$ tested according to IET/RT 86: $\overline{\Delta L}$ method. Age: 2 and 4 years.

consecuencias tecnológicas que del mismo puedan resultar.

$2^{\mathrm{a}}$ Tres de los 9 casos comparados con relación $\mathrm{a} / \mathrm{c}=0,495$ han mostrado disminución de los valores de $\overline{\Delta \mathrm{L}}{ }_{14 d}$ en lugar de aumento, y esto a pesar de que por el contenido de $\mathrm{C}_{3} \mathrm{~A}$ del cemento portland ensayado se debería haber obtenido todo lo contrario.

$3^{a}$ Existe un Grado de Finura de Molido ÓPTIMO de los cementos portland de elevada y moderada resistencia al ataque de los iones sulfato, mediante el cual sus probetas muestran un valor mínimo de $\overline{\Delta \mathrm{L}}{ }_{14 \mathrm{~d}}$ $<0,040 \%$ cuando se ensayan con alguna de las dos versiones del método ASTM C 452.

$4^{\mathrm{a}}$ Lo mismo se puede decir para alcanzar el objetivo contrario de la conclusión anterior, es decir, cuando el respectivo valor de $\overline{\Delta L}_{14 d}$ (especialmente de los cementos portland $\mathrm{PY}$ ) es mayor que $0,040 \%$ y menor que 0,073 a los 28 días (5). technological consequences that it may result.

2nd. Three cases of the 9 cases with $w / c=0.495$ compared have shown decreasing of the $\overline{\Delta L}_{14 d}$ velues as teh content of $C_{3} A$ in the Portland cement increased, in instead of being increased as it would expected.

3rd. There is a grinding fineness optimum for moderte and high resistant to sulfate ion attack Portland cements, by which their specimens shown a minimum value of $\overline{\Delta L}_{14 d}<0.040 \%$ when they are tested with any of the two versions of AST'M C 452 for their respective qualification.

4th. The same could be said for all the contrary, that is to say, when the respective $\overline{\Delta L}{ }_{14 d}$ velue(especially for the PY Portland cement) is higher than $0.040 \%$ and lower than $0.073 \%$ at 28 days(5). 


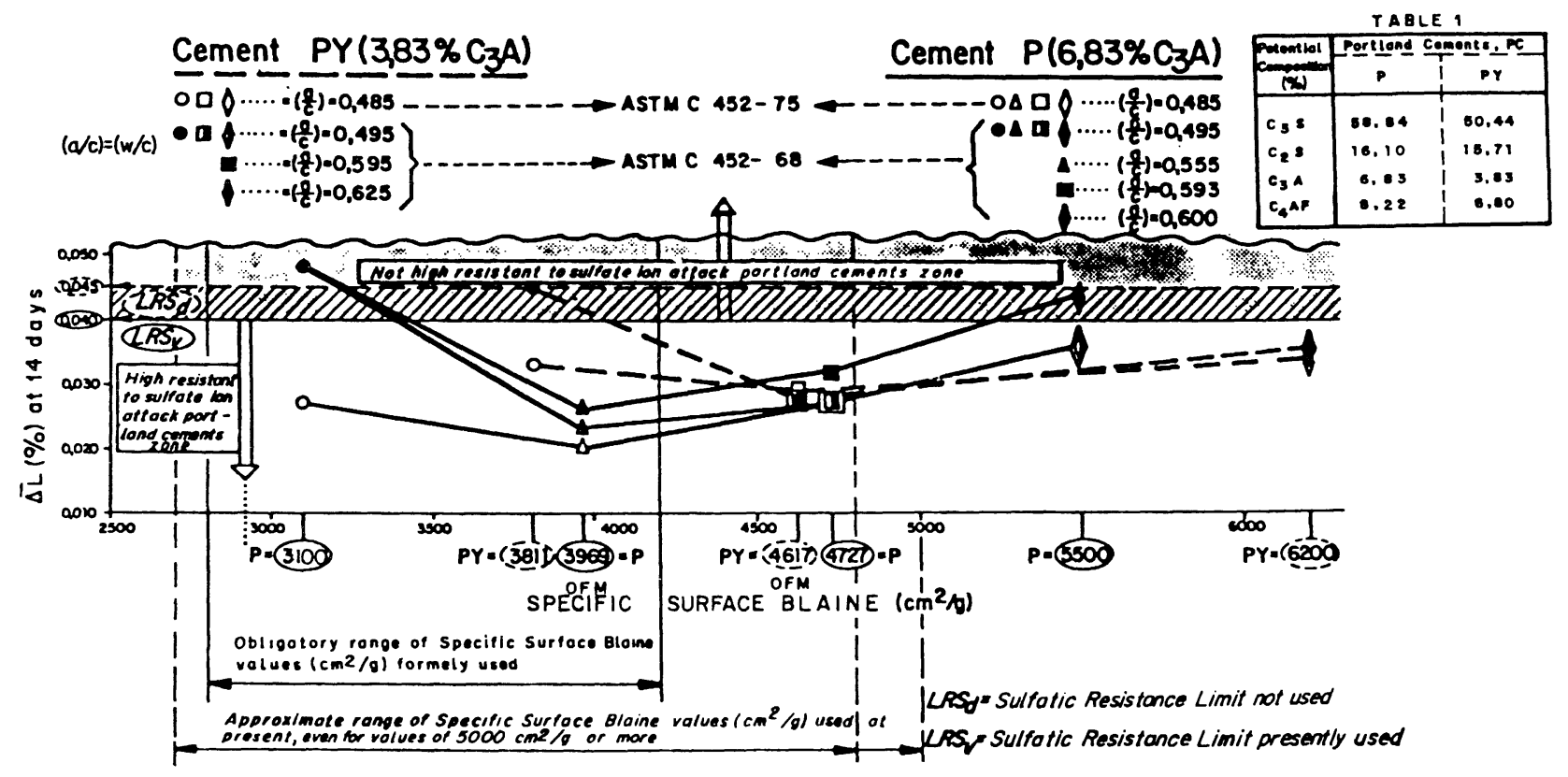

Fig 1.- El " Grado de Finura Óptimo " OFM, del cemento portland P, ha sido $3969 \mathrm{~cm}^{2} / \mathrm{g} \mathrm{y}$ el del cemento portland PY, 4617 $\mathrm{cm}^{2} / \mathrm{g}$.

Fig. 1.- The "Grinding Fineness Optimum" OFM, of the portland cement P has been $3969 \mathrm{~cm}^{2} / \mathrm{g}$, and of the portland cement PY has been $4617 \mathrm{~cm}^{2} / \mathrm{g}$

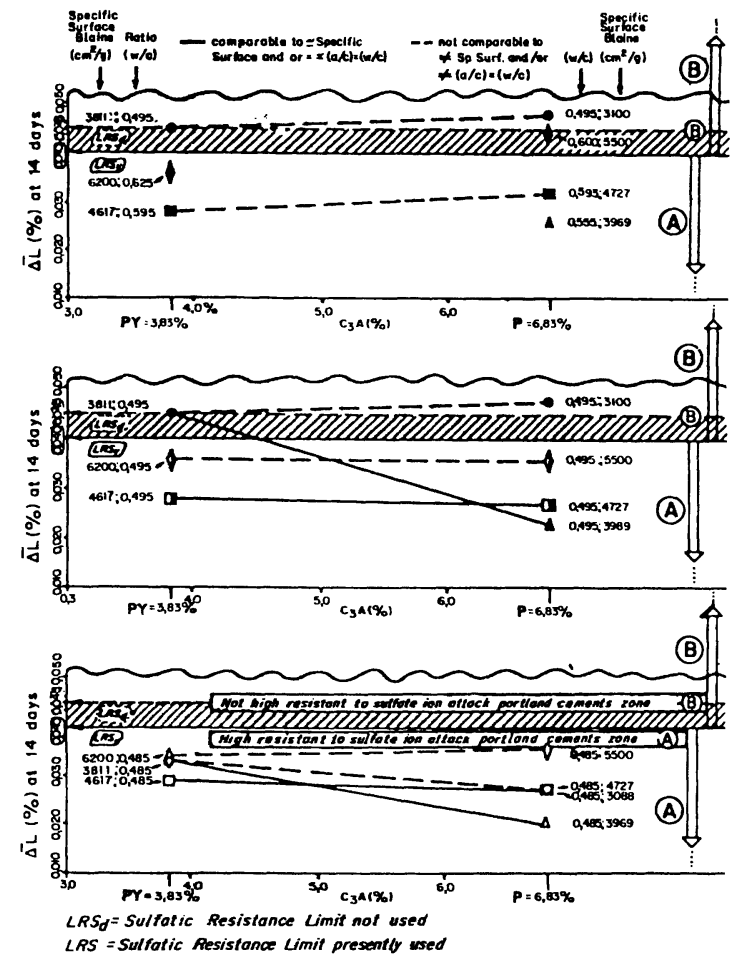

Fig. 2.- Comparación y calificación en cada caso,de los cementos portland $\mathrm{PY}\left(3,83 \% \mathrm{C}_{3} \mathrm{~A}\right)$ y $\mathrm{P}\left(6,83 \% \mathrm{C}_{3} \mathrm{~A}\right)$ en función del valor del $\Delta \overline{\mathrm{L}}_{14 \mathrm{~d}}$ de sus probetas de mortero ASTM C 452.

Fig.2.- Comparison of portland cements $P Y\left(3,83 \% C_{3} A\right)$ and $P\left(6,83 \% C_{3} A\right)$ as $f\left(\overline{L L}_{19 d}\right)$ in their respective ASTM C 452 mortar specimens and their calification for each case.
TABLA 1 (TABLE 1)

\begin{tabular}{|c|c|c|}
\hline$\%$ & $P(3,09)^{*}$ & $\operatorname{PY}(3,12)^{*}$ \\
\hline LOI & 2,31 & 2,28 \\
\hline IR & 0,62 & 0,54 \\
\hline $\mathrm{SiO}_{2}$ & 21,10 & 18,75 \\
\hline $\mathrm{Al}_{2} \mathrm{O}_{3}$ & 4,30 & 4,98 \\
\hline $\mathrm{Fe}_{2} \mathrm{O}_{3}$ & 2,70 & 5,52 \\
\hline $\mathrm{CaO}$ & 64,40 & 60,82 \\
\hline $\mathrm{MgO}$ & 1,31 & 2,59 \\
\hline $\mathrm{Na}, \mathrm{O}$ & 0,81 & 0,56 \\
\hline $\mathrm{K}_{2} \mathrm{O}$ & 0,21 & 0,23 \\
\hline $\mathrm{SO}_{3}$ & 2,30 & 3,72 \\
\hline $\mathrm{H}_{2} \mathrm{O}\left(105^{\mathrm{a}} \mathrm{C}\right)$ & 0,42 & 0,66 \\
\hline $\mathrm{CaO}$ libre(free) & 0,90 & 0,68 \\
\hline \multicolumn{3}{|c|}{ Mineralogía (Mineralogy) } \\
\hline $\mathrm{C}_{3} \mathrm{~S}$ & 58,84 & 50,44 \\
\hline $\mathrm{C}, \mathrm{S}$ & 16,10 & 15,71 \\
\hline $\mathrm{C}_{3} \mathrm{~A}$ & 6,83 & 3,83 \\
\hline $\mathrm{C}_{4} \mathrm{AF}$ & 8,22 & 16,80 \\
\hline $\mathrm{C}_{4} \mathrm{AF}+2 \mathrm{C}_{3} \mathrm{~A}$ & 21,88 & 24,46 \\
\hline $\mathrm{C}_{4} \mathrm{AF}+\mathrm{C}_{3} \mathrm{~A}$ & 15,05 & 20,63 \\
\hline
\end{tabular}

* Densidad (Density) $\left(\mathrm{c} / \mathrm{cm}^{3}\right)$ 


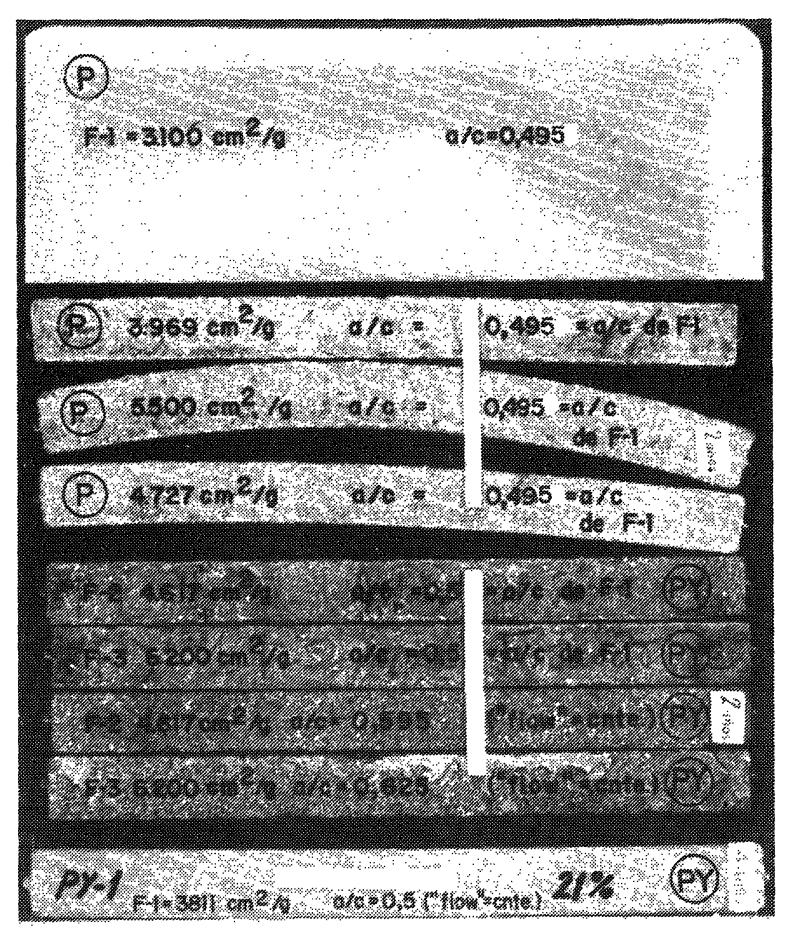

Foto 1.- Probetas de los cementos portland P y PY ensayados según el método IET/RT 86: $\overline{\Delta L}$. Edad 2 y 4 años.

Photo 1.- Specimens of the portland cements $P$ and $P Y$ tested according to IET/RT 86: $\overline{\Delta I}$ method. Age: 2 and 4 years.

consecuencias tecnológicas que del mismo puedan resultar.

$2^{\mathrm{a}} \quad$ Tres de los 9 casos comparados con relación $\mathrm{a} / \mathrm{c}=0,495$ han mostrado disminución de los valores de $\overline{\Delta \mathrm{L}}{ }_{14 \mathrm{~d}}$ en lugar de aumento, y esto a pesar de que por el contenido de $\mathrm{C}_{3} \mathrm{~A}$ del cemento portland ensayado se debería haber obtenido todo lo contrario.

$3^{a}$ Existe un Grado de Finura de Molido ÓPTIMO de los cementos portland de elevada y moderada resistencia al ataque de los iones sulfato, mediante el cual sus probetas muestran un valor mínimo de $\overline{\Delta L}_{14 \mathrm{~d}}$ $<0,040 \%$ cuando se ensayan con alguna de las dos versiones del método ASTM C 452.

$4^{\mathrm{a}}$ Lo mismo se puede decir para alcanzar el objetivo contrario de la conclusión anterior, es decir, cuando el respectivo valor de $\overline{\mathrm{L}}_{14 \mathrm{~d}}$ (especialmente de los cementos portland PY) es mayor que $0,040 \%$ y menor que 0,073 a los 28 días (5). technological consequences that it may result.

2nd. Three cases of the 9 cases with w/c 0.495 compared have shown decreasing of the $\overline{\Delta L}_{14 d}$ velues as teh content of $C_{3} A$ in the Portland cement increased, in instead of being increased as it would expected.

3rd. There is a grinding fineness optimum for moderte and high resistant to sulfate ion attack Portland cements, by which their specimens shown a minimum value of $\overline{\Delta L} \bar{L}_{14 d}<0.040 \%$ when they are tested with any of the two versions of ASTM C 452 for their respective qualification.

4th. The same could be said for all the contrary, that is to say, when the respective $\overline{\Delta L}{ }_{14 d}$ velue(especially for the PY Portland cement) is higher than $0.040 \%$ and lower than $0.073 \%$ at 28 days(5). 
$5^{\mathrm{a}}$ De entre las dos versiones del método acelerado de ensayo ASTM C 452 empleado en este trabajo, la correspondiente a la relación $\mathrm{a} / \mathrm{c}=0,485$ es con la que las probetas de ambos cementos mostraron los menores valores de $\overline{\mathrm{L}}_{14 \mathrm{~d}}$. Esto confirma lo obtenido al respecto por $\mathrm{R}$. Talero en su Tesis Doctoral (5).

\section{INTERÉS TECNOLÓGICO}

Un cemento portland de "moderada resistencia" al ataque de los iones sulfato y un contenido de $\mathrm{C}_{3} \mathrm{~A}$ $<7,0 \%$ puede ser calificado, de acuerdo con la Tabla 2a "Requerimientos Físicos Opcionales" de la norma ASTM C 150-85, como de "elevada resistencia" a dicho ataque agresivo, haciendo que tenga un grado ÓPTIMO de finura de molido para dicho propósito, y después de haber sido ratificado por el método descrito en la norma ASTM C 452.

\section{RECOMENDACIONES PRÁCTICAS}

Ambas versiones del método acelerado de ensayo están siempre más próximas a un caso real de agresividad sulfática a un hormigón de cemento portland que a su contenido de $\mathrm{C}_{3} \mathrm{~A}$ (obtenido de manera estimativa mediante los cálculos de Bogue).

NOTA: Estas 5 conclusiones son válidas únicamente para cementos portland con contenidos de $\mathrm{C}_{3} \mathrm{~A}<7,0 \%$. 5th. Between the two versions of accelerated method of the ASTM C 452 employed in this work, the present one or ratio $w / c=0.485$, is the one by which the specimens of both cements show lower $\overline{\Delta L}_{14 d}$ values. this confirms what was obtained by R.Talero in his Doctorate Thesis(5).

\section{TECHNOLOGICAL INTEREST}

A Portland cement with moderte resistance to sulfate ion attack and a content of $C_{3} A-7.0 \%$, can be qualified ac'cording to the Table $2 a$ "Optional Fhysical Requirements" of the ASTM C. 150-85 standar as "high resistant to SIA" only verifying an adequate and optimum grinding fineness degree for such purpose, and after being tested by means of the method described by the ASTM C 452-75 standard.

\section{PRACTICAL RECOMENDATIONS}

Since both versions of the accelerated method of test are neare to any real case of a sulfate ion aggresivity to a Portland cement concrete than to the content of ( A (obtained by the estimation of Bogue calculus from the data resulted from the chemical analysis of the respective Portland cements) of that Portland cement.

NOTE: These conclusions are only valid for Portland cements with $C$ A contents $\because 7.0 \%$

\section{REFERENCIAS}

\section{REFERENCES}

(1) ASTM Bull. $n^{\circ} 212$ pág. 37-44, Feb- 1956

(2) American Society for Testing Materials "Standard Specification for Portland Cement" ASTM C 150-85.

(3) American Society for Testing Materials. Standard Test Method for Potential Expansion of Portland Cement Mortars Exposed to Sulfate. ASTM C 452-68.

(4) American Society for Testing Materials Standard Test Method for Potential Expansion of Portland Cement Mortars Exposed to Sulfate. ASTM C 452-75.

(5) R. TALERO: "Contribution to the Analytical and Physical Chemical Study of the System Pozzolanic Cements-GypsumWater" (at $21^{\circ} \pm 2^{\circ} \mathrm{C}$ ). Doctoral Thesis. Univ. Compl. de Madrid. Facultad de Ciencias Químicas. Madrid. Nov. 1986. 